\title{
Mooring in the Homeless City. A Practice Theoretical Account of Homeless Urban Dwelling and Emplacement
}

\author{
Natalia Martini \\ Jagiellonian University, Poland
}

DOI: https://doi.org/10.18778/1733-8077.17.3.03

\section{Keywords:}

Homelessness;

Dwelling; Spatiality;

Place; Mooring;

Theories of Practice

\begin{abstract}
Taking a practice theoretical approach and building on the research conducted with a group of people who live their lives on the streets of two Polish cities, this paper provides an account of the homeless city dwellers' mode of emplacement. It offers the terms licensed, invisible, motile, material, relational, affective, and ad hoc mooring to describe how homeless people establish a place of and for various activities that make up their everyday practice of inhabiting the city. While highlighting the accomplishments of homeless places, the paper also underscores their tentativeness and instability. It situates the homeless mode of emplacement within a wider landscape of normative urban geography, against which the ways homeless people establish themselves in place are often judged out-of-place. It attends to the role that this transgressive potential plays in limiting homeless dwellers' capabilities for mooring and considers how they might be enhanced.
\end{abstract}

Natalia Martini is a Doctoral Student at the Institute of Sociology, Jagiellonian University, Cracow, Poland. She is a sociologist with a background in cultural studies. She has a strong interest in urban everyday life and creative methodological approaches for studying its varied spatialities and temporalities. Her work cuts across sociology and human geography and favors an activist approach to scholarship.
Her current research focuses on everyday practices of inhabiting the city. It uses participatory, mobile, and reflexive methods to discover how homeless dwellers navigate the city and anchor their places in various urban spaces, and how their capabilities for exercising the right to stay put might be enhanced.

email address: natalia.martini@doctoral.uj.edu.pl 


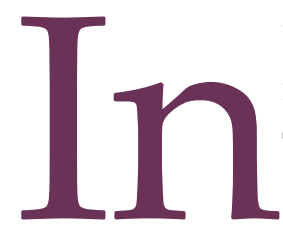

this paper, I provide a practice theoretical account of the homeless city. That is to say, I provide an account of the city rooted in everyday practices of dwelling carried out by homeless people. More particularly, I describe how homeless places are being established within the socio-material context of these practices. I engage with practice theoretical notions of spatiality and anchoring (Schatzki 2010) to develop an understanding of this situational and relational accomplishment of place, calling it "mooring," and consider it in terms of practical-material realization (Duff 2017) of the right to dwell.

By attending to the homeless inhabitation of the city (and the city emerging from that inhabitation) in its makings (Lancione 2020), I wish to unsettle the dominant representations of the homeless city as a landscape of despair (Dear and Wolch 1987) conjured solely by the disciplining structural forces framed as the "carceral city," the "revanchist city," or the "post-justice city" (for a detailed discussion of such framing of the homeless city, as well as a critique of its limitations, see: DeVerteuil, May, and von Mahs 2009). Without diminishing the role of the strategies deployed to control and contain homeless spatiality, I acknowledge the need to attend to "the ways in which homeless people themselves, rather than others" (Cloke, May, and Johnsen 2008:242) shape the contours of their lived urban world. Further, I recognize the need for bringing out the fact that there is more to a life lived in a homeless situation and concerning the urban than bare survival (Cloke, May, and Johnsen 2008; Lancione 2020) performed through more or less strategic coping or tactical adaptation. Instead of "survival," "strategies," and "tactics," I prefer to think about homeless urban dwelling in terms of certain ways of doing, governed by implicit logics of social practices, and certain agencies enabled by these logics. That is not to say I belittle the hardships of homelessness or ignore the constraints of homeless agencies. It is rather to suggest I acknowledge the necessity to emphasize that if we listen carefully to the voices from the homeless city, what we hear is not only a cry for help but also "a political demand for an ethical recognition" (Duff 2017:528) of how things are being done in and despite precarious circumstances. I respond to this demand by focusing on the situated efforts by which homeless people anchor their places in various urban spaces and thereby establish socio-material abutments of their lived urban world despite various attempts to eradicate, or at least control, the homeless spatiality through practices of containment, displacement, exclusion (Snow and Mulcahy 2001), and repression (Wright 1997), to name a few. Whilst not questioning the validity of the framing of the homeless urban dwelling as "continuous displacement" (Lancione 2016:172), which "cannot be considered apart from the experience of movement" (May 2000:737), I would suggest that it also cannot be considered apart from continuous struggle for a place more or less securely fixed in space. For one, existence (in a homeless situation or otherwise) as an embodied phenomenon unfolds in a place anchored in space. It necessitates space for a (homeless or not) body's place to be. Secondly, in the light of the experience of forced mobility, some form of stasis associated with a more permanent anchoring of one's place in space is what the homeless bodies crave for and put a lot of effort to achieve. At least this is what I learned from and with a group of people who live their lives on the streets of two Polish cities, Cracow and Lodz, whilst researching the practices of inhabiting the city in a homeless situation. Thus, in the remainder of this paper, I focus on the homeless dwellers' capabilities for mooring, that is, capabilities for accomplishing a place of and 
for various activities that make up their everyday practices of dwelling.

What I know about the homeless city, and report on here, I know from its dwellers and not from people whose job is to reach out, treat, manage, or get rid of them. Although my account will feature police officers, security guards, social workers, charity volunteers, and others who constitute intrinsic parts of the practice-arrangement bundles within which homeless places are being established, the focus is on homeless people. I believe they deserve full attention given the marginal position they occupy not only as urban dwellers but also as urban knowers. Homeless people rarely hold any epistemic authority (Fricker 2007), even over their lived circumstances (Kawash 1998), not to mention urban development or planning, or other things urban. Deemed un-inhabitants of the cities, they do inhabit, homeless people are often wronged "in their capacity as a subject[s] of knowledge" (Fricker 2007:5). Through my account, I wish to contribute to recognizing homeless people as knowledgeable and skillful practitioners of urban dwelling-especially a certain sort of it, a homeless one-and their mode of emplacement as "a proposition of its own standing" (Lancione 2020:34). I have structured it in the following way: I begin by introducing a theoretical and methodological approach to studying homeless urban dwelling as a constellation of embodied and emplaced practices of inhabiting the city. I then discuss various ways of mooring drawing on the results of my research conducted in Cracow and Lodz, as well as praxeological reading of other relevant accounts. I use the last section to consider homeless dwellers' capabilities for mooring in relation to the practical realization of their right to dwell, embedding my analysis in a broader debate on the right to the city. Finally, I reflect upon the possibilities of enhancing homeless dwellers' ca- pabilities for accomplishing place, highlighting the practical implications of my findings.

\section{Praxeologizing Homeless City and Place}

In this section, I outline the general assumptions of practice theoretical perspective and introduce key concepts used as a heuristic device with which I have approached the generation of knowledge about the homeless city presented in this account.

Practice theoretical perspective as a general framework through which social phenomena can be investigated is founded on a distinct social ontology (Schatzki 2001; 2018). According to its main ontological assertion, the social world is nothing but a vast, complex plenum of linked social practices and material arrangements (Schatzki 2016). In this sense, "bundles of practices and arrangements provide the material out of which [all] social phenomena, large and small, consist" (Schatzki 2011:6). Practices refer to arrays of activities, linked and governed by shared practical understandings, teleoaffectivities, and rules (Schatzki 1996), carried out by people involved in doing things (cooking, eating, driving, parking, praying, working, socializing, in generalliving); arrangements refer to nexuses of material entities (people, organisms, artifacts, and things) that channel the carrying out of activities. Central to this framework is the understanding of the social reality in terms of "enactment" (Mol 2002) - objects in the social world are constituted via recursive enactment in practice. They are brought into being and sustained through the recurrent performance of social practices entangled with material arrangements, that is, recurrent doing of things, circumscribed by implicit logic of practices, amid and with the use of material entities. Praxeologizing social phenomena means treating them as rooted in practice-arrange- 
ment bundles (Schatzki 2018) and attending to what, that is, which social and material components, is involved in their enactment (Sandberg and Dall'Alba 2009:1350). The conceptual repertoire of theories of practice provides an integrated way of conceptualizing the homeless city as a socio-material phenomenon established within everyday practices of dwelling performed by homeless people amid various arrangements of urban materiality. In developing the framework for this account, I engaged specifically with Theodore Schatzki's notion of spatiality to conceptualize homeless dwellers' practices as the sites at which the abutments of the homeless city in a form of places are being established, and the notion of anchoring to better understand the mechanics of their establishment.

Spatiality, in my interpretation of Schatzki's praxeological reading of this Heideggerian term, may be understood as a practice-specific mode of emplacement. It consists of the transformation of the milieu of human activity into a matrix of places of and for this activity (Schatzki 2010). Every social practice produces its spatiality by specifying the locale of its performance. It embraces an implicit understanding of "where" it is performable (sensibility of performance) or ought to be performed (normativity of performance). It articulates certain spaces (material entities and arrangements thereof) as places to perform actions of which it is composed, as material anchors for these actions, and defines their meanings vis-àvis these actions-a bed as a place to sleep, a table as a place to eat, a bathroom as a setting to carry out activities that make up a practice of maintaining personal hygiene. Thus, every practice implies certain rules of emplaced conduct-rules of anchoring places at material entities and their arrangements, that is, rules of handling people and things, and acting toward and amid them in places produced through this handling. If practices are regimes of performance (Nicolini 2017), then they necessarily are also regimes of placement. They circumscribe not only the "what" but also the "where" of routinized doing.

Spatiality, as a mode of emplacement, is localized in objective space through material anchoring. When carrying out a practice (performing actions that compose a practice) amid an arrangement of people and things, one proceeds through an array of places anchored at and amid, and thereby located at and amid, an objective spatial arrangement formed by those people and those things (Schatzki 2015). This arrangement of material entities, together with bodily performances of actions, form an objective spatial configuration (Schatzki 2015). Thus, when carrying out a practice one proceeds through a spatial arrangement, but "in its pertinence and involvement in [one's] activity" (Schatzki 2010:36), that is transformed into a set of places of and for this activity via its performance. Hence, a performance of practice constitutes as well its emplacement-it transforms a material entity, a setting, a three-dimensional space into a place of and for this practice. Therefore, a place may be considered an event. It is a lived space of interaction (Mallett 2004), constituted through "a gathering of elements that are themselves mutually defined only through how they are gathered together within the place they also constitute" (Malpas 2006:29). It "takes place" in an encounter of the acting human body-mind with the socio-materiality of the arrangement. Place happens.

Now, which places happen amid which material arrangements is a matter of convention as the use of certain objects (such as benches) or arrangements of objects (such as parks), and thus the anchoring of places in those objects and arrangements, is standardized within practices (Schatzki 2010:53). It is also 
a matter of power. For some practice-specific spatialities gain and sustain the status of "binding," whereby their modes of emplacement gain and sustain the status of "proper" within settings in which they are being performed. What is more, the dominant spatialities usually pass "the trial by space" (Lefebvre 1991), which means that the settings themselves are being purposefully designed and erected to house (anchor) their (and only their) arrays of places. They appropriate urban spaces and secure this appropriation through the naturalization of their arbitrariness (Cresswell 1996), enforced by, if necessary, other, more tangible means of defense. Other spatialities are judged inappropriate against these orthodox normative geographies and their performances are perceived as acts of transgression (Cresswell 1996). And for those whose modes of emplacement do not harmonize with the dominant spatialities, like homeless city dwellers, the "happening" of place cannot be taken for granted. Their capabilities for anchoring places in many urban spaces are limited, thus every successful anchoring, a "mooring," can be considered an accomplishment. Thusly conceived establishment of place within the socio-material context of homeless inhabitation of the city constitutes the object of my considerations presented in the remainder of this paper.

\section{Learning How to Dwell and Establish Place in the Homeless City}

In my attempt to apprehend the homeless city as a product of the everyday practices of homeless urban dwelling, I was guided by 36 people who live their lives on the streets ${ }^{1}$ of two Polish cities, Cracow

\footnotetext{
${ }^{1}$ In terms of the European Typology on Homelessness and Housing Exclusion developed by FEANTSA, their living situation might be described as "rooflessness," which means living rough or in emergency accommodation. See: https://www.
}

(the second largest and one of the oldest cities in Poland, an important academic, business, and tourism center, inhabited by approximately 1,062 people in the homeless situation), and Lodz (the third-largest city in Poland, a former industrial center, currently undergoing an intensive revitalization, inhabited by approximately $891^{2}$ people in the homeless situation). Between March 2018 and June 2019, I participated in a natural unfolding of their daily routines or reenactments of their typical mobilities and moorings during walk-alongs, a hybrid between participant observation, interviewing, corporeal engagement, and auto-observation (for a detailed discussion of the deployment of this method, see: Martini 2017; 2020; forthcoming). I was shown how and where things are being done-things that make up a daily life which is lived in a homeless situation and concerning the urban. And I attempted to learn how to do some of them. That is to say, I underwent a sort of practical training in homeless urban dwelling, engaging with homeless people in a peculiar form of pedagogy, with them guiding my process of learning how living in the city is routinely being done (which designates something substantially different than learning about this way).

This positionality enabled me not only to observe and to participate in the routines through which the homeless city is being enacted in practice but also to disrupt them. My disruptive, "incompetent," novice way of doing engendered learning situations (Schatzki 1996) where explicit formulations of implicit

feantsa.org/en/toolkit/2005/04/01/ethos-typology-on-homelessness-and-housing-exclusion. Retrieved June 01, 2019.

2 The number of homeless people in Cracow and Lodz according to the Polish Ministry of Family, Labor, and Social Policy data on homelessness gathered in a point-in-time headcount of February 2019. See: https://www.gov.pl/web/rodzina/wyniki-ogolnopolskiego-badania-liczby-osob-bezdomnych-edycja-2019. Retrieved June 01, 2019. 
logic of homeless urban dwelling as a social practice have occurred. Organizing research processes and procedures around the attempt to learn from homeless dwellers in a manner of an apprentice looking for guidance was crucial in overcoming the natural attitude (Giorgi 1970) towards daily routines and articulating the tacit understanding around which they are centrally organized. It allowed for an embodied and reflective immersion into the homeless city enacted in practice and apprehending it from within its logic that molds its making.

The analysis for the present article has been framed by one of the results of that immersion-the lived experience of the limited capabilities for mooring and the effort required to stay put in the homeless city. It has been informed by the notions of spatiality as a practice-specific mode of emplacement and mooring as a successful anchoring of a place in space via the performance of activities amid material arrangements. Procedurally speaking, the analytical and interpretative process involved (1) reading the research corpus (consisting of transcripts of the introductory pre-walking interviews; spatial transcripts, phenomenological descriptions, and visual documentation of the walk-alongs) through the notion of mooring to identify instances of successful anchorings (research question [RQ]: what are the examples of successful anchoring); (2) conducting within-case analysis (Miles and Huberman 1994) to characterize individual cases of successful anchorings (RQs: what kind of place has been accomplished; where and how it has been accomplished); (3) conducting cross-case analysis (Miles and Huberman 1994) to compare various cases of successful anchorings and identify distinctive and common features (RQs: what similarities and differences with regard to what/where/how are there between particular instances of mooring; what patterns of what/where/how combinations are there across cases). These steps facilitated the initial development of a typology of moorings refined through axial coding (Strauss and Corbin 1998) focused on uncovering the mechanics of particular types of moorings (RQ: under which conditions does a particular type of mooring occur), as well as diffractive reading (Mazzei 2014) of my findings. I read the results of my analysis and the insights from past research through one another, tracing the alignments of findings and the possibilities for consolidation of knowledge emerging from other, not necessarily practice-based, accounts of the homeless city.

\section{Mooring in the Homeless City}

In this section, I consider the complexities of accomplishing place within the socio-material context of homeless urban dwelling, where capabilities for mooring are limited as a homeless mode of emplacement is often judged transgressive. The following account comprises a mix of situated details (including particular places anchored in particular settings when I felt relatively sure that providing this information will not expose particular people) and more general ways of accomplishing place abstracted from the fieldwork experiences in Cracow and Lodz. In what follows, I will not focus on the particular sorts of places that punctuate the map of the homeless city (see, e.g., Cloke, May, and Johnsen 2008; Johnsen, May, and Cloke 2008), nor will I enumerate the sorts of spaces in which they usually occur (see, e.g., Snow and Anderson 1993; Perry 2013). Instead, I will describe the conditions and how these anchorings happen. Although the following types of moorings have been analytically distinguished on a basis of their main features, they are not mutually exclusive. ${ }^{3}$

\footnotetext{
${ }^{3}$ They also do not include the conditions and how home-like places are being accomplished, as my essential interest was held by the practices of inhabiting the city, not the practices
} 


\section{Licensed Mooring}

There are various settings (shelters, night shelters, day centers, warming centers, soup kitchens, and soup runs in the case of Poland) where homeless dwellers anchor their places under license, so to say. These are the spaces that one first learns about when down and out on the streets, from fellow members of the homeless scene or special maps and guides handed out by outreach workers and charity volunteers. These are the spaces that constitute what has been called the homeless archipelago (Gowan 2010), also the nodal territory of the homeless city (Cloke, May, and Johnsen 2010), where the basic needs can be met. Settings where "an individual's homeless status - conferred 'other' in most contexts-becomes the norm" (Cloke, May, and Johnsen 2008:252), and where certain "bodily appearances, odors, and...behaviors (for example, sleeping under a table) that might be deemed 'odd' or 'inappropriate' elsewhere are accepted without remark" (Parr 2000 as cited in Cloke, May, and Johnsen 2010:130). They accommodate various homeless places, from the better-known ones like places to sleep, eat, maintain personal hygiene, warm-up, or pass the time, to the, perhaps, less obvious, like places of sociality, conviviality, refuge, and care, but also, on the contrary, of frustration, anger, unease, and fear.

Given the license to "be as one is" operating in these settings, it may seem that accomplishing place in a service space should be effortless. But, as people from whom I have learned pointed out, whether they anchor their place in these settings depends on many things. First of all, it depends on whether

of domesticating urban space (for an account of these sorts of practices and these sorts of places, see, e.g., Groot and Hodgetts 2012; Rennels and Purnell 2017; Nóżka 2020). one is ready to bear the cost of admitting they need assistance, where the currency in the economy of asking for help is one's self-esteem and self-respect (also see: Hall 2017). Or, whether one is ready to publicly expose their shaming incapacity for taking care of daily necessities on their own when awaiting the provision of services, which usually happens outside of a setting and in a line, being the spatial formation that homeless bodies are expected to assume before entering, for example, a night shelter or a soup kitchen (also see: Bourlessas 2018). Second, it depends on whether one is willing or able to stay sober as the "rite of entrance" to many service spaces involves a sobriety test, known on the streets as "blowing into a breathalyzer." If you "blow zero or green," you are allowed to enter. If not, access (and a warm meal, a bed, a shower, an act of kindness or compassion, or whatever else is sought behind the doors) is usually denied. Or, whether one is willing to participate in religious practices that often constitute an inseparable component of services provided by faith-based (mostly Catholic in the case of Poland) organizations. It also depends on whether one can get used to living in conditions that would make "any normal person drop dead from a heart attack," which is how homeless dwellers described conditions in some, certainly not all, shelters in Cracow and Lodz. Or, whether one can get used to being told what and when is good or bad for them, or rather prefers solving their problems on their terms, like Alek, ${ }^{4}$ Jarek, Aga, and many other homeless people I have met. Taking all of this into account, many homeless dwellers choose to avoid service spaces (also see: Kawash 1998). But, to be fair, many do not. They appreciate (or just make use of) the support and take this opportunity to accomplish place.

\footnotetext{
${ }^{4}$ The names of the individuals mentioned in this paper have been changed.
} 
There is another license under which homeless dwellers anchor their places, the one which operates outside of the service nodes and is given by homeless people themselves rather than others. A license to "be as one is" (with an exception for violent behavior), which operates in settings that accommodate homeless places of sociability or more or less accidental groupings. So-called "drinking schools" (Archard 1979), for example, anchored at squares, in parks, or less visible residual spaces, are being established under such license. Deemed an offense against public order within the dominant normative geography, for homeless dwellers, they enact a place of inclusion where and when "everyone will have a seat, a talk, and a drink with everyone," as I was told in Lodz. But also, as I observed in both cities, where and when hands are being shaken, greetings exchanged, personal stories told, and pleasures of the company enjoyed-things that are much appreciated by homeless people given that what accompanies them is, most often, solitude. When places are being established under the license of communal association, homeless dwellers also conform to the rules of emplaced conduct, but the ones they regard as proper. The acceptability of their participation in these places is based on their standards of aesthetic appearance and appropriate behavior. What is more, being among others who know how it is to live on the streets, shelters homeless dwellers form the condescending views of those who "don't get it." And this means a temporal alleviation of the emotional burdens of social opprobrium, which operates outside of the licensed moorings.

\section{Invisible Mooring}

Beyond, not necessarily safe, havens of the homeless archipelago and judgment-free oases of communal gatherings, where and when "spoiled identities"
(Goffman 1963) of homeless dwellers start to stand out, the success of many of their anchorings relies on invisibility.

Social invisibility allows for establishing moorings in settings like shopping malls, libraries, or means of public transport. Homeless dwellers can appear in such settings when they do not meet "certain stereotyped characteristics ascribed to the imagined homeless body" (Schmidt 2015:286), or, in the homeless people's words, when they "look like human beings." "You have to make sure you are... you look like a human being. You can even get on the tram or go anywhere," was explained to me by Michał (in his fifties, living in Cracow for ten years, in a homeless situation also for ten years), "You can if you look like a human being." Keeping oneself clean, neat, and tidy, which at times involves literal washing off traces from one's body left by the homeless situation, like dust on one's clothes or grass in one's hair, entangled there after a night spent on the ground under the bushes, increases the ability to "look like a human being," that is, to appear as non-homeless. And this matters in accomplishing place, especially in public or semi-public spaces, because "those who are not perceived to be homeless are treated far better than those who are" (Rennels and Purnell 2017:503). It is as simple and as unjust as that.

Social invisibility, achieved through blending into the human backgrounds of various urban settings, is thus a precondition for many homeless moorings to happen. This "artful self-concealment" (Hopper 1991) involves careful attempts to disguise certain attributes that make a person identifiable as homeless. "When writing about this, don't forget to mention the gadgets given out by charities," said Aga (in her thirties, born and raised in Cracow, in a homeless situation for three years) while pointing out to 
bright yellow backpacks worn by a group of people we went past during our walk, soon after the World Day of the Poor celebrations were held in Cracow. "I call these backpacks homeless people's IDs. They sure help to identify us," she added. A bright yellow backpack is just one of the potentially stigmatizing attributes-mismatched clothes, worn-out shoes, plastic bags, ungroomed hair, bloated face; even the way one walks, sits, or smells may need concealment as giving away the spoiled identity of people living in the homeless situation. "I try to take care of my appearance," said Jarek (in his forties, living in Cracow for twenty years, in a homeless situation for four years) when commenting on these issues, "I try to look more or less, let's say, normal, you know, shaved, washed, well dressed. And people let me in some places."

Once self-concealed and let into a setting, homeless dwellers establish and affirm their presence through the pretended enactment of "proper" spatiality-pretending to be doing the shopping while actually anchoring a place to warm up, pretending to be browsing a library's catalog while anchoring a place to charge a phone, pretending to be going somewhere by bus while anchoring a place to pass the time. They need to be cautious, though not to reveal that they are in disguise. Not to ever forget that their anchoring is fleeting and accomplishment of place only temporary, that what they craft through the art of self-concealment is "a provisional, tentative, and always unstable space of appearance" (Duff 2017:524). They need to stay alert not to ever feel too comfortable on a sofa in a shopping center, on a chair in a train station waiting area, or in a back seat of a night bus, because if they do, the next thing they will most likely experience will be expulsion, punishment for an act of transgression committed through "improper" anchoring. I was walking with
Jadwiga (in her thirties, living in Cracow for a year, in a homeless situation for two years) around the Planty Park in Cracow when she drew my attention towards an older man sitting on one of the benches. "You see what they did to him?" she asked. His face was showing signs of physical violence. "Poor guy, he fell asleep in Galeria Krakowska," she commented. He closed his eyes in a temporarily accomplished place of respite, rendering the true character of his anchoring visible, and experienced punishment for trespassing "the limits of what is considered permissible" (Wikström 2005:52) by those guarding the "proper" mode of emplacement in a shopping mall setting.

Not everyone is equally capable of or willing to render their homelessness status invisible-this is particularly not easy for "individuals with serious drug and/or alcohol addictions whose presence [in the settings mentioned above] is significantly more likely to appear 'out of place'"' (Johnsen, May, and Cloke 2008:203). Some anchorings are then being established through physical invisibility. Places to drink are usually accomplished in settings hidden from the sight of the authorities (in Poland, drinking in public spaces constitutes an offense punishable by a fine), places to beg-beyond the gaze of CCTV cameras. "If you'd like to have a drink here, you wouldn't sit on this bench," said Darek (in his forties, living in Cracow for six years, in a homeless situation for fifteen years) when asked about doing the "drinking" at one of the public squares in Cracow. "You'd rather choose that one, behind the parked cars, so the city guards wouldn't see you, but you'd be able to notice them coming." "You have to stand at such a point that the camera won't catch you and you won't get noticed by the security. And you can't stand for more than half an hour," said Marek (in his fifties, living in Lodz for three months, in a home- 
less situation for seven years) when explaining his way of accomplishing a panhandling place in front of one of the shopping malls in Lodz. Invisibility is also achieved through anchoring only at particular times of the day or night-between rounds of a security patrol in or outside of a shopping mall, before the arrival of passengers at a train station, after closing of a convenience store. Physical invisibility, achieved through meticulous positioning and scheduling of moorings in unmonitored points in time and space, allows for accomplishing a place beyond the regulatory gaze of social authority looking over the normative ordering of space, and securing the dominant position of "proper" spatiality.

There is another element of the regulatory apparatus operating in urban spaces that pushes homeless dwellers to disappear into their surroundings. That is disgust. Disgust "operates as means to exclude the body from the public, to relegate the body to the status of not visible" (Mathews 2019:6). Homeless people try to stay out of sight to avoid the voyeuristic stares they attract that mark a destabilization of public comfort (Boyer 2012). Comfort disrupted by the sight of the homeless body occupying space that is considered to be a transgressive mode of emplacement. Homeless dwellers emplace themselves in the hidden cracks of urban materiality to avoid meeting other people's eyes and seeing distaste and contempt in them. In other words, they disappear into the surroundings to salvage their dignity. They hide not to provoke a sense of dis-ease (Kearns 1993). Marek once gave me a tour around his nooks spread around the inner city of Lodz. He showed me an interstice, maybe one meter wide, between a concrete wall and a security booth in a parking lot, a stone at the back of a fast-food stand, and stairs leading to a hospital's basement, descending beneath the level of the sidewalk. "These are my nooks of peace and quiet," he said with a hint of tenderness in his voice. "This is where I can be aside, you know, keep myself to myself, where I don't cause unease among people, I don't embarrass them." Marek and other homeless dwellers that I have met were able to accomplish many places in such barely noticeable spaces-a place to sit, to rest, to eat, to drink, a place to be without being looked down on, a place to be without being hurt by the gestures and the looks, by the various forms of social opprobrium, in other words, they were able to establish a niche (Hall 2017) for themselves.

\section{Motile Mooring}

Sometimes the state of invisibility, and the accomplishment of place it enables, is being achieved through motility. ${ }^{5}$ Under certain circumstances, stillness may perform social difference and movement may constitute a way out of the process of "Othering." "If someone spends five hours just sitting, then, well, you know, something is wrong in their life," Bartłomiej (in his fifties, born and raised in Lodz, in a homeless situation for a year) told me when we were discussing the conditions of mooring in Manufaktura shopping center in Lodz. When spatial fixity starts to draw unwanted attention, homeless bodies begin to move. Their movement is either a means for disappearing from one location and appearing in another or a mode of emplacement in its own right. Homeless dwellers thus move either to simply change the site of the anchoring, to be somewhere else, or to establish a place on the move,

\footnotetext{
${ }^{5}$ I engage the notion of motility to describe how homeless dwellers accomplish place "on the move" and distinguish it from the notion of mobility often used to characterize their general existential condition (Radley et al. 2010) as in framings such as "being fixed in mobility" (Jackson 2015) or enacting an identity of a "mobile hermit" (Hodgetts et al. 2010) or a "drifter" (Bourlessas 2018).
} 
to be somewhere (as one needs some "where" to be) but nowhere specifically, as an alternate appearance and disappearance of the mobile body constitutes only momentarily localized presence. This is how, for instance, walking accommodates a place to pass the time. When homeless dwellers have nowhere to go (when space for their place is lacking), they keep on going. And as they walk, they either attend to the immediate urban environment, by pleasing their eyes with historical tenement houses, like Jarek used to do, or enjoying urban greenery, as Darek often did, or, on the contrary, they transcend it engaging in fantasy, distraction, or escapism (also see: Hodgetts et al. 2010). As a result, they accomplish a place that is not fixed in space.

\section{Material Mooring}

There are mundane things, seemingly worthless material objects, which mean a lot for homeless dwellers; a receipt, a ticket, a vacuum flask. These objects legitimize their presence. They afford them to be. They allow them to establish temporary moorings in settings where their presence would otherwise be perceived as out-of-place. A receipt from KFC or Burger King found in a trash bin or obtained from other customers, entitling to refills, beside a free soft drink, provides a legitimization of presence in the food court area in the Manufaktura shopping center in Lodz and mediates the anchoring of places to sit around and socialize. The cheapest ticket, bought at the Cracow Main Bus Station, provides a legitimization of presence in the waiting area and mediates the anchoring of places to warm up and shelter from the elements. A vacuum flask engraved with an inscription “Thermo-Coffee," obtained within a charity initiative, entitling to a free cup of coffee or tea, provides a legitimization of presence in several cafes in Cra- cow (participating in the initiative) and mediates the anchoring of places to be attended upon and treated with dignity.

Homeless places happen in forms of relatedness to objects also when homeless dwellers comb through urban spaces in search of things they may use-sell, wear, eat, drink, smoke, spend, et cetera. Cans are the reason Przemek (in his forties, born and raised in Lodz, in a homeless situation for twenty years) attends mass events organized at Atlas Arena (Lodz); unfinished drinks and leftover drugs draw Błażej (in his twenties, living in Lodz for most of his life, in a homeless situation for three years) to OFF Piotrkowska Center (Lodz) on Saturday mornings; lost wallets, cameras, and phones bring Jarek to Szewska Street (Cracow) on Friday nights. Thrown away food draws to the back of stores, cigarette leftovers to the entrances of university or hospital buildings, recyclable beer bottles to parks. These objects and their locations are in themselves the sites of performances of practices and thus constitute their (practice-specific) places, but they are also further possible places, as gathering of things and their further distribution within different settings within different practices establishes further places.

\section{Interpersonal Mooring}

Interpersonal moorings are established through forms of relatedness to people. From mere tangencies to complex relations. From an acquiescence to the presence of an anonymous homeless person to an acquaintance with a homeless dweller known by their name. A variety of homeless places happen by getting along with people-security guards, clerks, members of cleaning crews, students, ticket controllers, bus drivers-establishing acquaintances and then sustaining the goodwill of people who form 
part of the homeless city's social infrastructure or, as Darek once told me, "the links in the chain that helps you survive through the day."

Turning a blind eye to the presence of a homeless person by a member of the security staff in a shopping mall food court area allows for the anchoring of a place to ask for food. Doing the same in the parking lot in front of a grocery store allows for the anchoring of a place to earn. Not minding the presence of a homeless person on the stairwell by residents of a residential block allows for the anchoring of a place to sleep. It means a lot when people simply do not mind you being somewhere-I learned from the homeless dwellers. But, there are rules-they cautioned. Civility and tidiness. You have to always be polite and keep the site (of the anchoring) tidy. Otherwise, the site is compromised, and the anchoring is gone. At times, there are additional rules, as I later discovered, regarding, for example, the frequency or the time of the day of the anchoring, whether it may involve entering or just appearing near the premises. I remember being once explicitly reminded of the rules of establishing place when we sat with Mikołaj (in his sixties, living in Cracow for thirty-seven years, in a homeless situation for seventeen years) next to a grocery store entrance, where he was spending most of his time during the day. Once we sat, Mikołaj brought a can of beer out and opened it. The hissing sound drew the attention of a familiar clerk- “You can stay here but don't drink. If you wanna drink, go out there. Mikołaj, I'm telling you. You drink, you move. You don't drink, you're fine to stay."

Being known somewhere (which performs something more than simply being noticed) marks particular locations in the homeless city. A particular grocery store, a vegetable stand, or a sandwich bar visited by a particular homeless dweller regularly. Where temporary moorings are being recursively established within brief (but regular) interactions between owners or employees who give food to the visiting homeless. These brief interactions, which, once their pattern has been established, may even happen without any verbal exchange-just an appearance, a nod acknowledging this appearance, a handing down of produce, and an expression of gratitude-afford the anchoring not only of places to procure food but also of places to experience sympathy. It may not be the food that is being given (it may be hot water-to make coffee, or access to a power socket-to charge a phone, or scrap materials-to sell). There may not even be any giving involved (it may be letting a person sit in front of a store, letting stay on a bus, letting sleep in a trash bin shelter, letting claim recyclable bottles without a receipt). Or, to the contrary, there may be a rich repertoire of activities being performed, when the relational mooring is established not through brief interaction but more complex mutual relation when certain reciprocity is developed. Like in the case of Darek, whose daily emplacement in the food court area in the Galeria Krakowska shopping mall (Cracow) involved helping in one of the food stands, bringing dirty dishes, changing money, having friendly conversations with the staff, and being treated with a meal; or in the case of Marek, whose daily emplacement by the kiosk on Kilińskiego Street (Lodz) involved sitting, chatting over a cigarette, at times being let to borrow a needle and a thread to stitch a torn piece of clothing, and helping with closing the heavy metal kiosk's gates. Those moorings, besides the tangible benefits, afforded the uplifting experiences of being trusted and needed.

Central to any relational mooring is the form of relatedness to people, which results in the practical un- 
derstanding of the material arrangement, of which those people are part, as accessible for a homeless dweller. Accessible through the sympathy raised and nurtured and the rules of the anchoring of the homeless place established and adhered to.

\section{Affective Mooring}

People, as parts of material arrangements within which homeless places are being anchored, are also central to another type of mooring, but in a slightly different way-through affecting or being affected.

Begging practice, for instance, a basic source of income for many street urban dwellers, is essentially an affective practice. Begging pitches are being anchored where other people may be encountered. Encountered and affected through a direct approach or a mere exposure to the sight of a begging body. The emotional registers of a successful affective transition (Massumi 2002) that is supposed to happen in a begging encounter need not be positive-shock, guilt, fear, pity, frustration may be as effective "motives" for sparing some change as sympathy or compassion (although the latter kind is preferred). Whether one sits on cardboard in an underpass, or plays guitar on a busy pedestrian street, or meanders through a crowd spilling out of a train station, a homeless dweller transforms (or at least attempts at transforming) the atmospherics (Duff 2017) of these settings. One anchors their place to affect. Like Mikołaj, whose presence tempered the atmosphere of a doorway leading to a bakery and a grocery store where he regularly established himself shifting the affective capacities of otherwise unremarkable and affectively indifferent spatial arrangement. The following scene illustrates "the emotional traces of [this] affective transition" (Duff 2017:524).
Mikołaj sits in his regular spot in a recessed doorway. On his left, he has an entrance to a grocery store, on his right-to a bakery. He sits quite comfortably on his cardboard, leaning against a wall, sheltered from the elements. People notice him. It is impossible not to. He sits exactly in between the doors. He just sits there, yet his quiet presence still affects people, and they, in return, affect him.

A: Sir, would you like a toast? Asks a man on his way to the bakery.

Mikołaj: Pardon me? Asks Mikołaj, making sure that the question was addressed to him.

A: A toast? Man repeats.

Mikołaj: I will, yes, absolutely, thank you so much.

A: I'll order one.

Mikołaj: Great, of course.

Hardly half an hour passes, and a woman approaches Mikołaj.

B: How did you like the hunter's stew? She asks, referring to a meal she had left for him in this spot the day before.

Mikołaj: Oh, superb. It was yours, ma'am?

B: Yes, mine.

Mikołaj: Oh dear...

B: Here's some more, sir, and some bread, and a cake, too.

Mikołaj: Oh, dear Mother of God, thank you so much. Thank you, God bless you.

When the woman leaves, Mikołaj turns to me and says:

Mikołaj: You see, sweetheart? Why would I go anywhere? They get me things by themselves.

But, affective moorings may also work the other way around-when the success of the anchor- 
ing relies on the lack of affective transition where a homeless dweller is hoping that their appearance and presence will not affect anybody and will not alter the atmosphere of the setting. It was the affective atmosphere of relaxed leisureliness that was drawing Bartłomiej every single day (except when it was raining heavily or snowing) to the $3^{\text {rd }}$ of May Park in Lodz, where positive emotional registers could be felt, even among strangers. It was the judgment-free, truly public, one might say, the atmospherics of the gatherings formed around street musicians that were pulling Marek on weekends to Piotrkowska Street (Lodz) where he could relax, take his mind off of troubling things. What those and other settings with similar affective atmospheres afforded homeless dwellers is not only a place of respite but also a place to enact morethan-homeless identity and to have a temporal stance in the public, or if this would be too much to say, then at least in other-than-homeless assembly. Again, this has to do with their visibility. "People look at you differently there," said Bartłomiej about the park. "People don't look at you at all, they focus on the musician," said Marek about the street scene. What they meant, of course, is that they do not see you as homeless.

\section{Ad hoc Mooring}

One afternoon, I was sitting with Michał in a hall of a building at Sienna Street (Cracow) where medics from an NGO called Przystań Medyczna were supposed to check on his legs. While waiting we were talking about the city. "Do you have a favorite place in Cracow?" I asked. "This, right here, next to you. It's so nice talking to you here," he said. "It's very kind of you to say, Michał," I replied, thinking that he was not answering my question, rather flirting. "But, seriously." It was only later that I have realized that he was serious and was telling me about his favorite place-a place that was happening right then and there, a place "at the moment," as two other homeless dwellers that I have met and learned from called this sort of mooring. Both Alek (in his forties, living in Cracow for thirteen years, in a homeless situation for fifteen years) and Darek (already mentioned), though independently, when asked if there was a place that they call their own, said: "Own place, in my case, is the one where I am; it is here where I am" (Alek) and "Own, that is where I am at a given moment. A place at the moment. I can claim it, right? Because I am in this moment" (Darek).

Leaving aside the fact that what took me a long paragraph to describe (I am referring to the notion of place as an event, elaborated on in the theoretical section), they were able to capture in one brilliant sentence (each); what else is there is an overarching way of accomplishing place within the socio-material context of homeless inhabitation of the city, a capability for mooring that homeless dwellers develop within their "tenacity to cope" (Ruddick 1996) - a capability for establishing place and evoking a sense of belonging in that place through and within an event of appearance. The sort of place established ad hoc may vary according to the end pursued (an action performed) in the moment of appearance. The mode of appearance itself may vary, that is, it may be performed in various ways, such as motility or stillness. The point is that within the limited capacity to remain in place, to develop, and sustain relatively stable teleoaffective forms of relatedness to space, homeless dwellers draw upon their capacity to appear in place in making space available for the unfolding of their spatiality and constituting a self-determined time and space or a timespace (Schatzki 2010) of belonging. 


\section{Enhancing Capabilities for Mooring in the Homeless City}

Having described how homeless dwellers accomplish a place of and for various activities that make up their mode of doing the "living" in the city, in this section, I reflect upon the possibilities of enhancing their capabilities for mooring. This has implications for supporting homeless dwellers in staking their claim to urban life, as the capability for anchoring one's place in space is a necessary condition for exercising one's right to dwell. If dwelling is a practice of being-in-the-world (Shields 1991:52) and being emerges only in and through the place (Malpas 2006:6), then, paraphrasing Jeremy Waldron (1993 as cited in Mitchell and Heynen 2009:614), to dwell, one must have a place to dwell. What is more, if being is embodied, and bodies occupy space, then a place to dwell necessitates space. Thus, the right to dwell issues from a "bodily demand" (Duff 2017) for space for and of its place. Mundane efforts to accomplish place that I have described in this paper may be thus considered as everyday struggles for the right to dwell, and capabilities for mooring as crucial resources in these struggles insofar as they are understood as socio-material conditions of establishing place. As such, they bear importance for the practical-material realization of the right to the city founded upon the right to habitat and to inhabit (Lefebvre 1996; Mitchell and Heynen 2009; Duff 2017).

In this regard, the importance of neutralization of transgression for enhancing homeless dwellers' capabilities for mooring should be stressed. First, it should be noted that transgression is not a guerilla-like tactic employed by homeless people to resist exclusion. On the contrary, success in everyday struggles for place performed by homeless dwellers usually depends on them not being noticed, that is, on them not being transgressive. In this, I follow Tim Cresswell (1996:23) who argues that "transgression, in distinction to resistance, does not, by definition, rest on the intentions of actors but the results-on the 'being noticed' of a particular action," and that "transgression is judged by those who react to it." Resistance, in the form of practical appropriation of space (Casey, Goudie, and Reeve 2008), if not done carefully, becomes transgression, which fosters the defense of the proper. Hence, one way of enhancing homeless resistance would be to neutralize its transgressive potential. ${ }^{6}$ How could that be achieved? At least three ways come to mind.

Firstly, we may focus more on exposing the violence of orthodox appropriation of urban spaces by the dominant spatialities, that is, in many contemporary cities, by the spatialities produced by housed, middle-class lifestyles. Having transgressed the dominant spatialities during my fieldwork, and having faced, at times violent, reactions that this "trespassing" brought about, I experienced the existence of boundaries that are controlled and defended, so that those whose modes of emplacement harmonize with the dominant spatialities can comfortably proceed through an array of places secured through the displacement of "Others." I realized the existence of displacing effects of "functional fixedness" assumed by this dominant logic of inhabiting the city, which is based on "an abstract notion of place; [as if] places are fixed and their function is determined in advance" (Kawash 1998:333). Having seen urban spaces in their practical intelligibility for homeless dwellers, having seen what else (what other places) they can, and in practice do, afford, I realized

\footnotetext{
${ }^{6}$ Another would be supporting their voice (Wright 1997), but this is beyond the scope of this paper.
} 
that this dominant functionalism is a form of strategic (Certeau 1984) concealment of possibilities if it truly is that within practical engagements with the environment "we see not shapes but possibilities" (Lingis 1996:14). The dominant logic of urban dwelling through its "powerful mechanism for policing proper uses of the city and the proper places for its residents" (Kawash 1998:333) makes it hard to see possibilities (other than those which correspond with the proper). Nonetheless, the possibilities are there. Possibilities of different uses of the city, and thus of different urban places. But, those who try to make use of them, like homeless city dwellers, often face hostility to their transgressive mode of emplacement.

Secondly, and consequently, we may think of tinkering with the sense of the proper mode of emplacement for it to embrace at least some of the uses of urban spaces circumscribed by the homeless practices of dwelling. This is what is being done, to a certain extent, by the Homeless Bill of Rights ${ }^{7}$ that legitimizes certain homeless anchorings through validating specific activities that produce and necessitate these anchorings. An awareness-raising campaign, described by Rennels and Purnell (2017:508), provides another example: "Several benches at bus stops and in parks [in Vancouver] have been modified so that they can fold out like airplane tray tables into miniature emergency shelters...During the day, UV letters on the benches react with sunlight revealing the phrase, 'This is a bench.' At night, a different message is revealed with glow-in-thedark letters, which read: "This is a bedroom.'” This

\footnotetext{
${ }_{7}$ A form of legislation affirming civil and human rights of homeless dwellers, for instance, access to and use of public space, propagated among local authorities in EU countries by FEANTSA and Housing Rights Watch. See: https://www. feantsa.org/en/network/2016/11/17/housing-rights-watch. Retrieved June 01, 2019.
}

endeavor may easily be read as an attempt at normalization of transgressive anchoring, resulting in the harmonization of supposedly conflicting modes of emplacement, and thus creating a setting that accommodates different spatialities.

Thirdly, we may let the homeless accomplishment of place to "speak its proposition" and provide additional support for its realization, for instance, in a form of infrastructure. A paradigmatic example of an infrastructure that enhances homeless city dwellers' capabilities for mooring is sanitary facilities given the crucial role played by physical appearance (also see: Langegger and Koester 2016) in achieving social invisibility and the variety of anchorings it enables. Another one would be us becoming an infrastructure given how many homeless places happen via forms of relatedness to people. We may intermediate interpersonal moorings through material entities like a receipt pinned on a board in one of the restaurants participating in action "Suspended Dinner" in Lodz where a homeless dweller (or other in need) may enjoy a meal paid in advance, or we may participate in them directly in places like Zupa na Plantach, a soup run that happens every Sunday evening in Cracow city center where cultivating relations with homeless dwellers is as important as providing them with a bowl of soup.

And if all of this is too much to suggest and wish for, then we may at least decide not to be a part of the exclusionary apparatus operating in urban spaces by simply not expressing our distaste (if this is what we feel) when a homeless dweller appears next to us on a street, in a park, or on a bus. We may at least not interfere with their accomplishment of place. Not displace them from a place "at the moment." 


\section{Lessons Learned from the Homeless City}

In this paper, I presented a practice theoretical account of the situational and relational accomplishment of place within the socio-material context of homeless inhabitation of the city. Engaging with the notions of spatiality and anchoring, I developed an understanding of the practice-specific mode of emplacement and used it to explore how homeless dwellers establish a place of and for various activities that make up their practice of inhabiting the city. By analyzing licensed, invisible, motile, material, relational, affective, and ad hoc moorings, I also provided the characterizations of the conditions under which successful homeless anchorings occur, and thus created a space for reflection in terms of the possible enablement of homeless spatiality. In this regard, I stressed the importance of the neutralization of the transgressive potential of homeless dwellers' mode of emplacement, that is, the neutralization of its potential to be judged as improper against the dominant spatialities. I further suggested that this might be achieved either through tinkering with the sense of the proper via legal or social interventions into the dominant logic of inhabiting the city, or supporting homeless dwellers' ways of resisting the dis-

\section{References}

Archard, Peter. 1979. Vagrancy, Alcoholism, and Social Control. London: Macmillan.

Bourlessas, Panos. 2018. “'These People Should Not Rest': Mobilities and Frictions of the Homeless Geographies in Athens City Centre." Mobilities 13(5):746-760.

Boyer, Kate. 2012. "Affect, Corporeality, and the Limits of Belonging: Breastfeeding in Public in the Contemporary UK." Health \& Place 18(3):552-560. placing effects that the appropriation of spaces by arrays of places through which only the privileged few are allowed to proceed has on the "Others." Homeless dwellers are not the only ones subject to the displacing effects of the city within which only particular spatialities are granted the status of proper. For the disabled (Butler and Bowlby 1997), mentally distressed (Knowles 2000), or breastfeeding (Mathews 2019) urbanites, to name a few, the capabilities for mooring are also limited. Therefore, the approach and the findings presented in this paper may prove useful in researching and supporting other marginal and marginalized spatialities.

\section{Acknowledgments}

The study reported in this article was approved by the Ethics Committee of the Department of Philosophy of the Jagiellonian University. The work was supported by the Polish National Science Center under grant no. 2016/23/N/HS6/00810. I am grateful to the homeless dwellers from Cracow and Lodz for all they taught me. I thank Marcjanna Nóżka for her ceaseless support, as well as Karol Kurnicki and two anonymous reviewers for their helpful comments on an earlier version of this article.

Butler, Ruth and Sophia Bowlby. 1997. "Bodies and Spaces: An Exploration of Disabled People's Experiences of Public Space." Environment and Planning D: Society and Space 15(4):411-433.

Casey, Rionach, Rosalind Goudie, and Kesia Reeve. 2008. "Homeless Women in Public Spaces: Strategies of Resistance." Housing Studies 23(6):899-916.

Certeau, Michel de. 1984. The Practice of Everyday Life. Berkeley, CA: University of California Press. 
Cloke, Paul, Jon May, and Sarah Johnsen. 2008. "Performativity and Affect in the Homeless City." Environment and Planning D: Society and Space 26(2):241-263.

Cloke, Paul, Jon May, and Sarah Johnsen. 2010. Swept Up Lives?: Re-Envisioning the Homeless City. Chichester: Wiley-Blackwell.

Cresswell, Tim. 1996. In Place/Out of Place: Geography, Ideology, and Transgression. Minneapolis, MN: University of Minnesota Press.

Dear, Michael J. and Jennifer R. Wolch. 1987. Landscapes of Despair: From Deinstitutionalization to Homelessness. Princeton: Princeton University Press.

DeVerteuil, Geoffrey, Jon May, and Jürgen von Mahs. 2009. "Complexity Not Collapse: Recasting the Geographies of Homelessness in a 'Punitive' Age." Progress in Human Geography 33(5):646-666.

Duff, Cameron. 2017. "The Affective Right to the City." Transactions of the Institute of British Geographers 42(4):516-529.

Fricker, Miranda. 2007. Epistemic Injustice: Power and the Ethics of Knowing. Oxford: Oxford University Press.

Giorgi, Amedeo. 1970. Psychology as a Human Science: A Phenomenologically Based Approach. New York: Harper \& Row.

Goffman, Erving. 1963. Stigma: Notes on the Management of Spoiled Identity. New York: Simon \& Schuster.

Gowan, Teresa. 2010. Hobos, Hustlers, and Backsliders: Homeless in San Francisco. Minneapolis, MN: University of Minnesota Press.

Groot, Shiloh and Darrin Hodgetts. 2012. "Homemaking on the Streets and Beyond." Community, Work E Family 15(3):255-271.

Hall, Tom. 2017. Footwork: Urban Outreach and Hidden Lives. London: Pluto Press.

Hodgetts, Darrin J. et al. 2010. “The Mobile Hermit and the City: Considering Links between Places, Objects, and Identities in Social Psychological Research on Homelessness." British Journal of Social Psychology 49(2):285-303.

Hopper, Kim. 1991. "Symptoms, Survival, and the Redefinition of Public Space: A Feasibility Study of Homeless People at a Metropolitan Airport." Urban Anthropology 20(2):155-175.

Jackson, Emma. 2015. Young Homeless People and Urban Space: Fixed in Mobility. Milton Park, New York: Routledge.
Johnsen, Sarah, Jon May, and Paul Cloke. 2008. “Imag(in)ing 'Homeless Places': Using Auto-Photography to (Re)Examine the Geographies of Homelessness." Area 40(2):194-207.

Kawash, Samira. 1998. "The Homeless Body." Public Culture 10(2):319-339.

Kearns, Robin A. 1993. "Place and Health: Towards a Reformed Medical Geography." The Professional Geographer 45(2):139-147.

Knowles, Caroline. 2000. Bedlam on the Streets. New York: Routledge.

Lancione, Michele. 2016. “Beyond Homelessness Studies.” European Journal of Homelessness 10(3):163-176.

Lancione, Michele. 2020. "Underground Inscriptions." Cultural Anthropology 35(1):31-39.

Langegger, Sig and Stephen Koester. 2016. "Invisible Homelessness: Anonymity, Exposure, and the Right to the City." Urban Geography 37(7):1030-1048.

Lefebvre, Henri. 1991. The Production of Space. Oxford: Blackwell Publishing.

Lefebvre, Henri. 1996. “The Right to the City." Pp. 63-181 in Writings on Cities, edited by E. Kofman and E. Lebas. Oxford: Blackwell.

Lingis, Alphonso. 1996. Sensation: Intelligibility in Sensibility. Atlantic Highlands, NJ: Humanities Press.

Mallett, Shelley. 2004. “Understanding Home: A Critical Review of the Literature." The Sociological Review 52(1):62-89.

Malpas, Jeff. 2006. Heidegger's Topology: Being, Place, World. Cambridge, MA: MIT Press.

Martini, Natalia. 2017. "Capturing the Lived Experience of the City through Methodological Practice of Walking." Pp. 303-317 in Re-Imagining the City. Municipality and Urbanity Today from a Sociological Perspective, edited by M. Smagacz-Poziemska, K. Frysztacki, and A. Bukowski. Cracow: Jagiellonian University Press.

Martini, Natalia. 2020. “Using GPS and GIS to Enrich the WalkAlong Method." Field Methods 32(2):180-192.

Martini, Natalia. forthcoming. "Walking with Homeless Persons in Kraków and Łódź." In Deathworlds to Lifeworlds: Collaboration with Strangers for Personal, Social, and Ecological Justice, edited by V. M. Bentz and J. Marlatt. Berlin: De Gruyter Press. 
Massumi, Brian. 2002. Parables for the Virtual: Movement, Affect, Sensation. Durham: Duke University Press.

Mathews, Vanessa. 2019. "Reconfiguring the Breastfeeding Body in Urban Public Spaces." Social \& Cultural Geography 20(9):12661284.

May, Jon. 2000. “Of Nomads and Vagrants: Single Homelessness and Narratives of Home as Place." Environment and Planning D: Society and Space 18(6):737-759.

Mazzei, Lisa A. 2014. "Beyond an Easy Sense: A Diffractive Analysis." Qualitative Inquiry 20(6):742-746.

Miles, Matthew B. and A. Michael Huberman. 1994. Qualitative Data Analysis: An Expanded Sourcebook. Thousand Oaks, CA: Sage.

Mitchell, Don and Nik Heynen. 2009. “The Geography of Survival and the Right to the City: Speculations on Surveillance, Legal Innovation, and the Criminalization of Intervention." Urban Geography 30(6):611-632.

Mol, Annemarie. 2002. The Body Multiple: Ontology in Medical Practice. Durham: Duke University Press.

Nicolini, Davide. 2017. "Practice Theory as a Package of Theory, Method and Vocabulary: Affordances and Limitations." Pp. 1934 in Methodological Reflections on Practice Oriented Theories, edited by M. Jonas, B. Littig, and A. Wroblewski. Cham: Springer International Publishing.

Nóżka, Marcjanna. 2020. "Rethinking Homelessness. Residence and the Sense of Home in the Experience of Homeless People." Housing, Theory, and Society 37(4):496-515.

Perry, Samuel L. 2013. "Urban Hybrid Space and the Homeless.” Ethnography 14(4):431-451.

Radley, Alan et al. 2010. "From Means to Occasion: Walking in the Life of Homeless People." Visual Studies 25(1):36-45.

Rennels, Tasha R. and David F. Purnell. 2017. "Accomplishing Place in Public Space: Autoethnographic Accounts of Homelessness." Journal of Contemporary Ethnography 46(4):490-513.

Ruddick, Susan M. 1996. Young and Homeless in Hollywood: Mapping Social Identities. New York: Routledge.

Sandberg, Jörgen and Gloria Dall'Alba. 2009. "Returning to Practice Anew: A Life-World Perspective." Organization Studies 30(12):1349-1368.
Schatzki, Theodore. 1996. Social Practices. A Wittgensteinian Approach to Human Activity and the Social. Cambridge: Cambridge University Press.

Schatzki, Theodore. 2001. "Introduction: Practice Theory." Pp. 10-23 in The Practice Turn in Contemporary Theory, edited by T. Schatzki, K. Knorr Cetina, and E. Von Savigny. London, New York: Routledge.

Schatzki, Theodore. 2010. The Timespace of Human Activity: On Performance, Society, and History as Indeterminate Teleological Events. Lanham, MD: Lexington Books.

Schatzki, Theodore. 2011. "Where the Action Is (On Large Social Phenomena Such as Sociotechnical Regimes)." Sustainable Practices Research Group Working Papers. Retrieved October 15, 2019 (http://www.sprg.ac.uk/uploads/schatzki-wp1.pdf).

Schatzki, Theodore. 2015. "Spaces of Practices and of Large Social Phenomena." EspacesTemps.Net. Retrieved October 15, 2019 (http://www.espacestemps.net/articles/spaces-of-practices-and-of-large-social-phenomena/).

Schatzki, Theodore. 2016. "Practice Theory as FLat Ontology." Pp. 28-42 in Practice Theory and Research. Exploring the Dynamics of Social Life, edited by G. Spaargaren, D. Weenink, and M. Lamers. London, New York: Routledge.

Schatzki, Theodore. 2018. “On Practice Theory, or What's Practices Got to Do (Got to Do) with It?" Pp. 151-65 in Education in an Era of Schooling: Critical Perspectives of Educational Practice and Action Research. A Festschrift for Stephen Kemmis, edited by C. Edwards-Groves, P. Grootenboer, and J. Wilkinson. Singapore: Springer Singapore.

Schmidt, Katharina. 2015. “Seeing the 'Homeless City'? Some Critical Remarks on the Visual Production of Homelessness through Photography." European Journal of Homelessness 9(2):283-303.

Shields, Rob. 1991. Places on the Margin: Alternative Geographies of Modernity. Milton Park, New York: Routledge.

Snow, David A. and Leon Anderson. 1993. Down on Their Luck: A Study of Homeless Street People. Berkeley, CA: University of California Press.

Snow, David A. and Michel Mulcahy. 2001. "Space, Politics, and the Survival Strategies of the Homeless." American Behavioral Scientist 45(1):149-169.

Strauss, Anselm L. and Juliet M. Corbin. 1998. Basics of Qualitative Research: Techniques and Procedures for Developing Grounded Theory. Thousand Oaks, CA: Sage. 
Wikström, Tomas. 2005. "Residual Space and Transgressive Spatial Practices-the Uses and Meanings of Un-Formed Space." Nordisk Arkitekturforskning 18(1):47-68.
Wright, Talmadge. 1997. Out of Place: Homeless Mobilizations, Subcities, and Contested Landscapes. Albany, NY: State University of New York Press.

\section{Citation}

Martini, Natalia. 2021. "Mooring in the Homeless City. A Practice Theoretical Account of Homeless Urban Dwelling and Emplacement." Qualitative Sociology Review 17(3):56-75. Retrieved Month, Year (http://www.qualitativesociologyreview.org/ENG/ $\vdots$ archive_eng.php). DOI: https://doi.org/10.18778/1733-8077.17.3.03 